\title{
Complexity of the Relationship between Environmental Factors, Interspecific Competition, and Intrinsic Traits of the Species in Explaining the Invasive Success of Gobio lozanoi Doadrio \& Madeira, 2004
}

\author{
Sandra Barca ${ }^{1, * \mathbb{D}}$, Rufino Vieira-Lanero ${ }^{2} \mathbb{D}$, David José Nachón ${ }^{1}{ }^{\mathbb{D}}$, Javier Sánchez-Hernández ${ }^{3} \mathbb{D}$, \\ María del Carmen Cobo ${ }^{4}$ and Fernando Cobo ${ }^{1}$ (D)
}

Citation: Barca, S.; Vieira-Lanero, R.; Nachón, D.J.; Sánchez-Hernández, J.; Cobo, M.d.C.; Cobo, F. Complexity of the Relationship between

Environmental Factors, Interspecific Competition, and Intrinsic Traits of the Species in Explaining the Invasive Success of Gobio lozanoi Doadrio \& Madeira, 2004. Water 2021, 13, 3043. https://doi.org/10.3390/w13213043

Academic Editor: José

Luis Sánchez-Lizaso

Received: 28 September 2021

Accepted: 27 October 2021

Published: 1 November 2021

Publisher's Note: MDPI stays neutral with regard to jurisdictional claims in published maps and institutional affiliations.

Copyright: (C) 2021 by the authors. Licensee MDPI, Basel, Switzerland. This article is an open access article distributed under the terms and conditions of the Creative Commons Attribution (CC BY) license (https:// creativecommons.org/licenses/by/ $4.0 /)$
1 Departamento de Zooloxía, Xenética e Antropoloxía Física, Facultade de Bioloxía, Universidade de Santiago de Compostela, 15782 Santiago de Compostela, Spain; davidjose.nachon@usc.es (D.J.N.); fernando.cobo@usc.es (F.C.)

2 Estación de Hidrobioloxía "Encoro do Con", Universidade de Santiago de Compostela, 36617 Vilagarcía de Arousa, Spain; rufino.vieira@usc.es

3 Área de Biodiversidad y Conservación, Departamento de Biología y Geología, Física y Química Inorgánica, Universidad Rey Juan Carlos, 28933 Madrid, Spain; javier.sanchezh@urjc.es

4 Department of Biological Sciences, University of Alabama, Tuscaloosa, AL 35487, USA; mariadelcarmen.cobo@usc.es

* Correspondence: sandra.barca@usc.es

\begin{abstract}
The increase of non-native species in rivers is of great concern. To assess the potential impact of a species it is necessary to consider the ecological state of the receiving ecosystem and the biology of the potentially invasive species. In this work we characterize two populations of Gobio lozanoi Doadrio \& Madeira, 2004 (bio-metric and demographic parameter) and the invasibility (as a function of habitat quality, competing species, food supply, etc.) of the two rivers that they inhabit. In addition, biomarkers of energy reserve level are analyzed to investigate their role in the invasiveness of the species. The results show differences in energy reserve levels and invasiveness between the two fish populations, and differences in the potential invasibility of the two tributaries. In the river with lower resistance to invasion, the G. lozanoi population is well-structured, and specimens have higher lipid values. On the contrary, in the river with better ecological status (and therefore greater resistance to invasion) we found lower lipid values, higher protein values and low juvenile survival rate. The lipid level is revealed as a good indicator of invasiveness in populations of alien species, under favorable conditions for invasion.
\end{abstract}

Keywords: non-native species; invasiveness; invasibility; biomarkers; interspecific competition; freshwater fish; lipids; Iberian Peninsula

\section{Introduction}

Throughout history, and as a consequence of human activity, many species have been introduced worldwide out of their natural distribution range. More recently, this trend has increased exponentially [1-4]. Not all non-native species become invasive [5,6], but when they do, they seriously affect the new ecosystem, modifying it through different causes and in different ways [7-10]. Therefore, invasive species are considered a major threat [1,2,11-14], included in the set of indicators for evaluating and monitoring biodiversity [15].

The detection of non-native species in Galicia (Northwest of the Iberian Peninsula) is recent compared with the rest of the Iberian Peninsula, probably due to its geographical isolation. Nonetheless, a strong increase has been observed in the last decade [16]. One of these species is Gobio lozanoi Doadrio \& Madeira, 2004. The natural distribution of G. lozanoi is the Iberian basins of the Ebro and Bidasoa rivers, and the French basins of the Adour 
and Nivelle rivers [17], but it has been translocated to numerous basins, including the Miño River [17]. In this basin it has been detected in at least four tributaries: Pego, Caselas, Furnia, and Hospital rivers (own data).

Generally, it is accepted that a previously disturbed ecosystem has less "biotic resistance" to new disruptions. Therefore, the existence of previous disturbances is one of the main factors favorable to invasions $[6,18,19]$. Besides, a proper native species diversity, linked to an efficient use of resources, or a non-disturbed ecosystem, turns into fewer "empty niches" that would allow invasive species to succeed [20]. Consequently, the success of an invasion decreases as the number of residents in the community, interspecific competition, and environmental variation increase [21]. Likewise, invasive non-native species have intrinsic biological traits that enhance their competitive ability and contribute to their expansion and displacement of native species $[5,6]$. Thus, invasibility is an intrinsic property of ecosystems that determines the survival rate of non-native species $[6,18,22]$, while invasiveness refers to the capacity of the species to be invasive [6]. Understanding these two factors is essential to evaluate the potential impact of a particular non-native species.

Energy reserve levels have been proposed as sensitive indicators of condition in fish [23]. Glycogen is the main form of storage of carbohydrates in animal tissues and is mostly found in muscle and liver. Much of the ATP required for fish activity (prey, escaping, swimming against the current, etc.) comes from the degradation of muscle glycogen storage, and their consequent glycolysis [24]. In addition, liver carbohydrate reserves, stored as glycogen, are modified during stress situations [25-27]. Lipids are the main source of energy reserve in fish, since they are consumed in activities of highenergy demand, such as reproduction and migration, or in periods of scarce resources. Consequently, lipid levels give an idea of growth strategies and survival $[23,28,29]$. Finally, protein contents indicate the energy reserves in the long term [30]. Thus, glycogen, lipids, and proteins respond to different types of developmental conditions and are considered as non-specific reserve levels biomarkers.

For this work, different biometric and demographic parameters of two populations of G. lozanoi (Pego and Caselas) were analyzed to determine their invasiveness. The invasibility of the receiving ecosystems was also evaluated in terms of key environmental resistance factors (ecological and habitat quality, competing species, food supply, etc.). In addition, the two populations of G. lozanoi were considered as models to investigate the role of energy reserve levels in the invasiveness of the species, and to evaluate the potential use of related biomarkers as a tool in non-native species research. Glycogen, lipid, and protein levels in each sample were determined as short-, medium-, and long-term energy reserve material, respectively.

\section{Materials and Methods}

Two rivers, tributaries of the final section of the Miño River, were considered for this study: Pego River (9.5 km long) and Caselas River (11 km long). The Strahler's hydraulic order (Strahle, 1957) of the Pego River and Caselas River are two and three respectively, at a scale of 1:25,000 (Figure 1). These rivers were included in a previous study on physicochemical and hydromorphological characteristics, which provided an accurate baseline information for the present work [31,32].

Sectors with the same biotopes were selected, as required by electrofishing and Surber net sampling and for future compressions. The sampled area was of $100 \mathrm{~m}$ long in both rivers with an average width of $3.5 \mathrm{~m}$ in the Pego River and of $3.8 \mathrm{~m}$ in the Caselas River, including areas with depths from $15 \mathrm{~cm}$ to $90 \mathrm{~cm}$. The substrate in both rivers is composed mainly of fine and coarse gravel, with some blocks and accumulations of sand in the depositional areas. The vegetation, both aquatic and riverbank, was similar in the sampled sections of both rivers [31,32].

Two sampling campaigns were conducted in each river, one week in July and one week in August, in three consecutive years (2017 to 2019). Field work included hydromor- 
phological, physicochemical [31,32], and biological characterization (macroinvertebrates and ichthyofauna). In addition, 60 individuals of Gobio lozanoi (30 from each river) were selected for the biomarkers' analysis. These specimens were preserved at $-80{ }^{\circ} \mathrm{C}$ before the laboratory analysis.

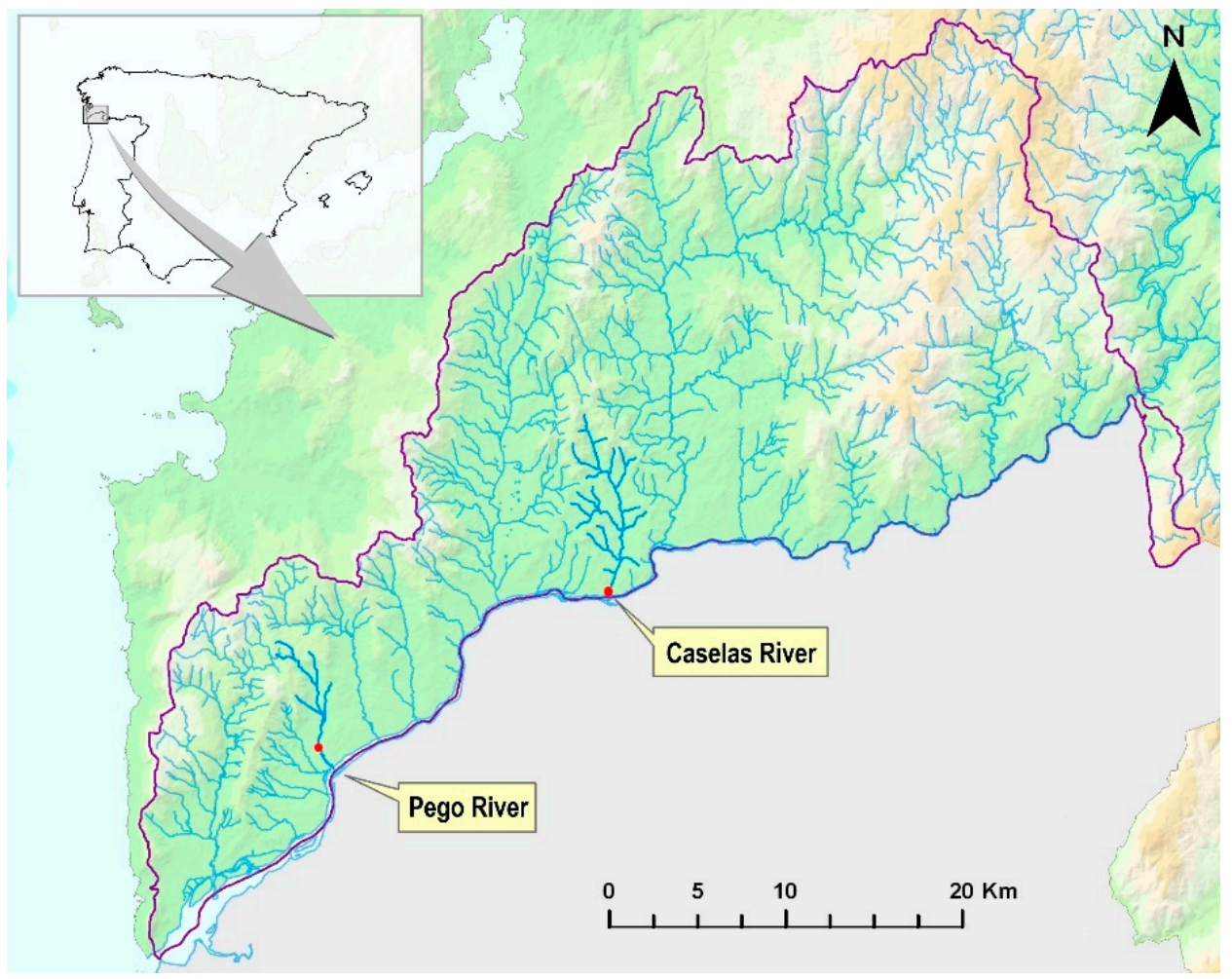

Figure 1. Location of the two studied tributaries in the final section of the Miño River.

The biological characterization of the macroinvertebrate community included the determination of the taxonomic richness (families), absolute abundance, density (ind $/ \mathrm{m}^{2}$ ), and the Shannon-Wiener, Simpson, Fisher, Pielou, and IBMWP (Iberian Bio-Monitoring Working Party) indexes. The IBMWP is an adaptation of the British index BMWP (Biological Monitoring Working Party) made by Alba Tercedor \& Sanchez-Ortega [33] for the rivers of the Iberian Peninsula. Values of the IBMWP biotic index were interpreted according to the thresholds proposed by González \& Cobo [34]. Sampling of the benthic macroinvertebrates were conducted with a Surber net (three samples per station considering all the bed substrates in the two rivers: sand, sand/mud, rocks, and vegetation). Samples were transferred to the laboratory preserved in water and formaldehyde (4\%). Macroinvertebrates were sorted in the laboratory and identified at family level.

Ichthyofauna was sampled using electric fishing (following the European standard UNE-EN 14011: "Sampling of fish with electricity") with a Hans Grassl backpack equipment model ELT 60II HI and direct current. The captured specimens were stored, protected under shade, in large capacity buckets with fresh water. The water was constantly renewed. To facilitate their manipulation (for identification and measurements) fish were anaesthetized with benzocaine $(6 \mathrm{~mL} / 20 \mathrm{~L}$ of water). All animals except the subsample of G. lozanoi (60 individuals), were returned to the river. The specific density (individuals $/ \mathrm{m}^{2}$ ) of each species was calculated.

Of the captured individuals 687 were G. lozanoi (399 from the Caselas River and 288 from the Pego River). In the field, the specimens were weighted (W, g; using scales with an accuracy of $\pm 0.01 \mathrm{~g}$ ) and the furcal length (FL, $\mathrm{cm}$ ) of each specimen was measured with an ichthyometer (WaterMark model; accuracy: $\pm 1 \mathrm{~mm}$; fish up to $60 \mathrm{~cm}$ ). The relative weight of the stomach contents was determined for each specimen and the Fulton condition factor $(\mathrm{K})$, was calculated as $\mathrm{K}=100 \times(\mathrm{W}, \mathrm{g}) /(\mathrm{FL}, \mathrm{cm})$. The age of every specimen was 
determined by studying the scales under the stereomicroscope following the procedure of Amat-Trigo et al. [35]. Scales (about 10 for specimen) were extracted from the left body flank, between the beginning of the dorsal fin and the lateral line.

Energy reserve levels from the muscle tissue were quantified using the following methods: the colorimetric method of anthrone [36] for glycogen; a variant of the method of Folch et al. [37] (in which the ratio of chloroform-methanol is modified to 1:1 and in some cases 1:2 [38]) for lipids; and the Thermo Scientific Pierce BCA Protein Assay kit based on the colorimetric method of bicinconic acid (BCA [29]) for proteins.

Statistical analyses were performed with the IBM SPSS $25^{\circledR}$ software, using nonparametric tests, because data did not follow a normal distribution (Shapiro-Wilk normality test, $\mathrm{n}<30$, and Kolomogorov-Smirnov, $\mathrm{n}>30$ ). The non-parametric test of Kruskall Wallis was applied to detect the existence of statistical differences between the groups, at a significance level $(\alpha)$ lower or equal to 0.05 .

\section{Results}

\subsection{Characterization of Tributaries}

According to Vieira-Lanero et al. [31] the rivers Pego and Caselas show similar hydromorphological conditions. The quality of the riverbank forest and the river habitat index indicate a worse habitat quality in the Pego River [31]. In addition, the physicochemical analyses (Table 1) show state of organic enrichment in this river. This condition does not generate significant oxygen deficits, but compromises the river's self-purification process, consequently the Pego River has higher ammonium and nitrite values (Table 1) [32].

Table 1. Physicochemical parameters of the studied rivers. TDS: total dissolved solids. * Extrapolated data below the detection limit (LDD) LDD Nitrites: $0.035 \mathrm{mg} / \mathrm{L}$; LDD Orthophosphates: $0.5 \mathrm{mg} / \mathrm{L}$. Adapted from [32].

\begin{tabular}{lcc}
\hline Parameters & Pego River & Caselas River \\
\hline $\mathrm{pH}$ & 5.94 & 6.33 \\
Temperature $\left({ }^{\circ} \mathrm{C}\right)$ & 17.6 & 14.1 \\
Conductivity $(\mu \mathrm{S} / \mathrm{cm})$ & 80.7 & 103.7 \\
TDS $(\mathrm{mg} / \mathrm{L})$ & 51.7 & 66.3 \\
Oxygen Saturation $(\%)$ & 87.0 & 88.5 \\
Dissolved Oxygen $(\mathrm{mg} / \mathrm{L})$ & 8.3 & 9.0 \\
Turbidity $(\mathrm{UNT})$ & 0.50 & 1.19 \\
Ammonium $(\mathrm{mg} / \mathrm{L})$ & 0.141 & 0.035 \\
Nitrites $\mathrm{NO}_{2}^{-}(\mathrm{mg} / \mathrm{L})$ & $0.009 *$ & $0.003^{*}$ \\
Nitrates $\mathrm{NO}_{3}{ }^{-}(\mathrm{mg} / \mathrm{L})$ & 7.33 & 11.54 \\
Sulphates $\left(\mathrm{mg}^{*} / \mathrm{l}\right)$ & 5.45 & 8.73 \\
Orthophosphates $(\mathrm{mg} / \mathrm{L})$ & $0.02 *$ & $0.01^{*}$ \\
Chlorides $(\mathrm{mg} / \mathrm{L})$ & 13.83 & 19.50 \\
Calcium $\mathrm{Ca}^{++}(\mathrm{mg} / \mathrm{L})$ & 2.20 & 3.21 \\
Magnesium $\mathrm{Mg}{ }^{++}(\mathrm{mg} / \mathrm{L})$ & 0.97 & 2.19 \\
Hardness $\left(\mathrm{mg}^{*} \mathrm{~L}\right)$ & 9.5 & 17 \\
Suspended solids $(\mathrm{mg} / \mathrm{L})$ & 10.9 & 20.4 \\
\hline
\end{tabular}

The ecological status of the tributaries was determined according to the values of the IBMWP biotic index [33] following González \& Cobo [34]. In the Pego River the index value was 81 , which corresponds to a deficient ecological state. In the Caselas River the index value was 120, showing a moderate state, with water of acceptable quality, not significantly altered. Table 2 shows the basic ecological parameters of the macroinvertebrates in both rivers.

Regarding ichthyofauna, 12 species were captured in the Pego River and 13 in the Caselas River. In general, specific densities (individuals $/ \mathrm{m}^{2}$ ) were higher in the Pego River (Table 3). Of the captured species three are non-native and were present in both rivers: Gobio lozanoi, Gambusia holbrooki Girard, 1859, and Lepomis gibbosus (Linnaeus, 1758). The 
non-native species represent 20.8\% in the Pego River and, $19.2 \%$ in the Caselas River. The ratio of relative density of non-native/native species is 0.26 in the Pego River and 0.24 in the Caselas River.

Table 2. Values of the descriptive parameters of the macroinvertebrate communities in both rivers. Taxonomic richness (Families), absolute abundance, density (ind $/ \mathrm{m}^{2}$ ) and values of Shannon-Wiener, Simpson, Fisher, Pielou, and IBMWP indexes.

\begin{tabular}{lcc}
\hline Parameters & Pego River & Caselas River \\
\hline Taxonomic richness $(S)$ & 26 & 23 \\
Absolute abundances & 919 & 443 \\
Density (individuals $\left./ \mathrm{m}^{2}\right)$ & 2756 & 1328 \\
Shannon-Wienner Index $\left(H^{\prime}\right)$ & 2.66 & 1.22 \\
Simpson Index $\left(D^{\prime}\right)$ & 0.28 & 0.17 \\
Fisher Index (a) & 4.79 & 2.38 \\
Pielou Index $\left(J^{\prime}\right)$ & 0.58 & 0.27 \\
Biotic Index (IBMWP) & 81 & 120 \\
\hline
\end{tabular}

Table 3. Density (individuals $/ \mathrm{m}^{2}$ ) of fish species. ND: not detected ( ${ }^{*}$ Non-native species).

\begin{tabular}{|c|c|c|}
\hline Species & $\begin{array}{l}\text { Pego River } \\
\text { (Indiv./m²) }\end{array}$ & $\begin{array}{l}\text { Caselas River } \\
\text { (Indiv./m²) }\end{array}$ \\
\hline Gobio lozanoi * & 0.22 & 0.12 \\
\hline Anguilla anguilla & 0.16 & 0.19 \\
\hline Pseudochondrostoma duriense & 0.06 & 0.06 \\
\hline Salmo salar & 0.06 & 0.04 \\
\hline Salmo trutta & 0.2 & 0.11 \\
\hline Petromyzon marinus & 0.02 & 0.02 \\
\hline Achondrostoma arcasii & 0.23 & 0.07 \\
\hline Cobitis paludica & 0.14 & 0.02 \\
\hline Platichthys flesus & 0.010 & 0.002 \\
\hline P. duriense $x A$. arcasii & 0.001 & 0.005 \\
\hline Gambusia holbrooki * & 0.001 & 0.002 \\
\hline Lepomis gibbosus* & 0.01 & 0.002 \\
\hline Atherina presbyter & ND & 0.0004 \\
\hline
\end{tabular}

\subsection{Characterization of the Two Populations of Gobio lozanoi}

Significant differences were found in the furcal length, weight, and condition factor between the two populations, with the latter being higher in the Caselas River (Table 4, Figure 2).

Table 4. Average \pm standard error (range) of the furcal length, weight, and condition factor of the individuals of G. lozanoi in the two analyzed populations.

\begin{tabular}{lcccc}
\hline River & $\mathbf{N}$ & Furcal Length $(\mathbf{c m})$ & Weight $\mathbf{( g )}$ & Condition Factor (K) \\
\hline \multirow{2}{*}{ Pego } & \multirow{2}{*}{288} & $7.30 \pm 0.11$ & $6.50 \pm 0.28$ & $1.36 \pm 0.01$ \\
& & $(3.4-11.5)$ & $(0.4-21.4)$ & $(0.88-1.98)$ \\
Caselas & 399 & $8.50 \pm 0.08$ & $9.30 \pm 0.24$ & $1.390 \pm 0.008$ \\
& & $(4.8-13.2)$ & $(2.0-27.4)$ & $(0.96-1.95)$ \\
\hline
\end{tabular}

Additionally, the study of the scales allowed to establish five age classes for G. lozanoi. The age distribution in the Pego River corresponds to a well-structured population, while in the Caselas River there is a low survival rate of class 1+ and a clear dominance of adult individuals of class 2+ (Figure 3). 

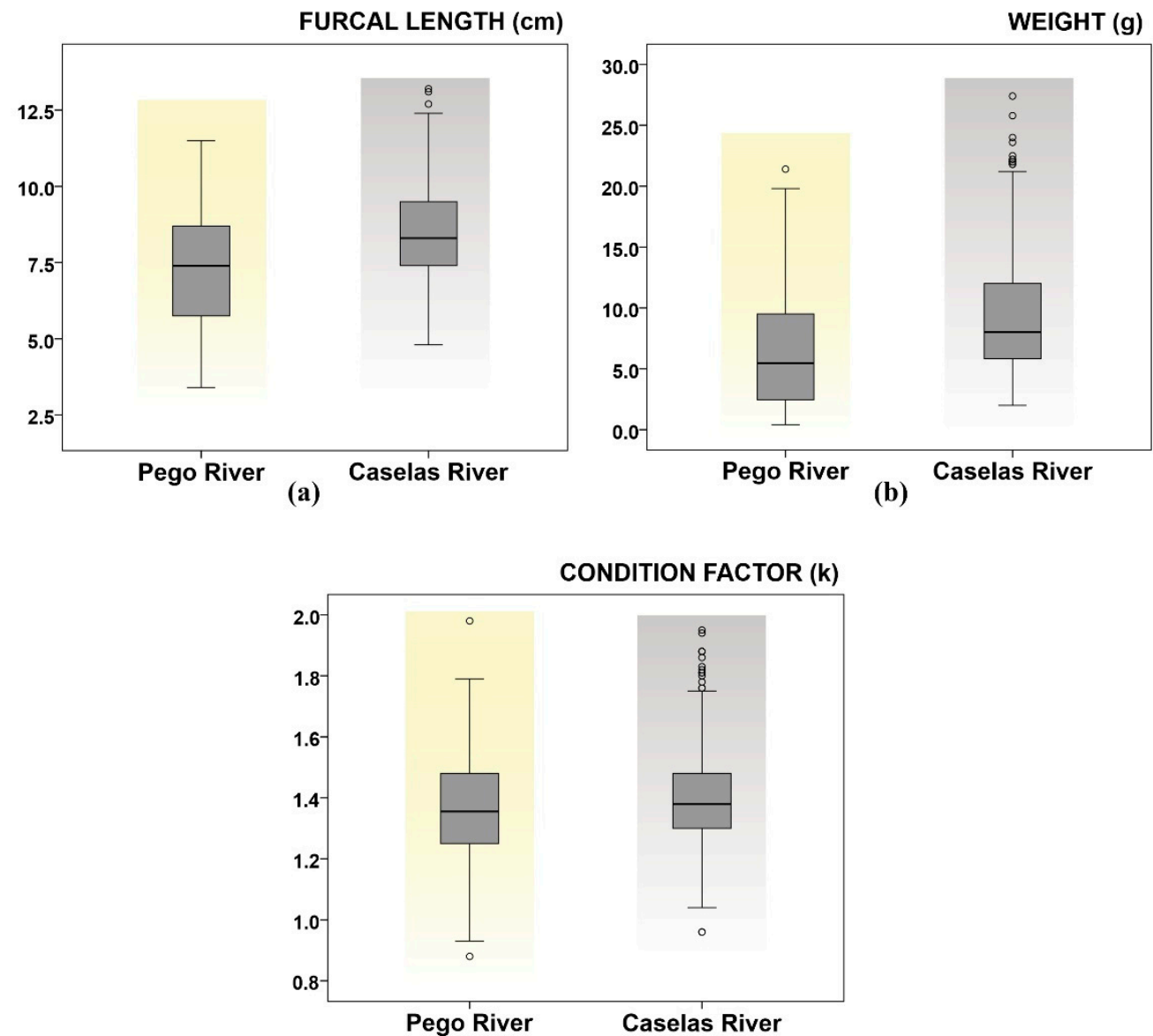

(c)

Figure 2. Box plot (median, quartiles, maximum, and minimum) of the (a) furcal length, (b) weight and (c) condition factor in the two studied populations of G. lozanoi.

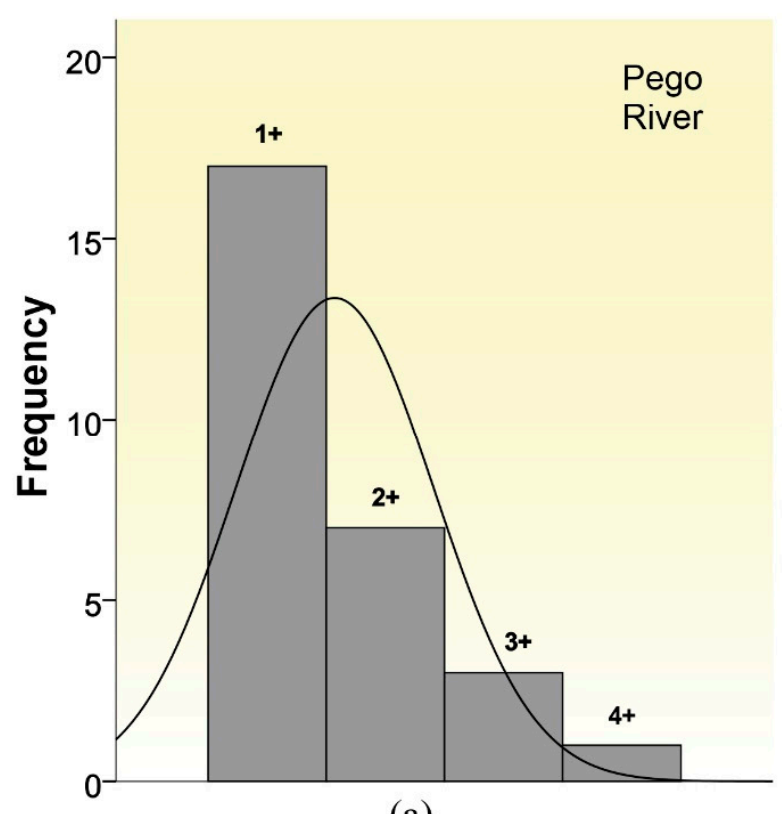

(a)

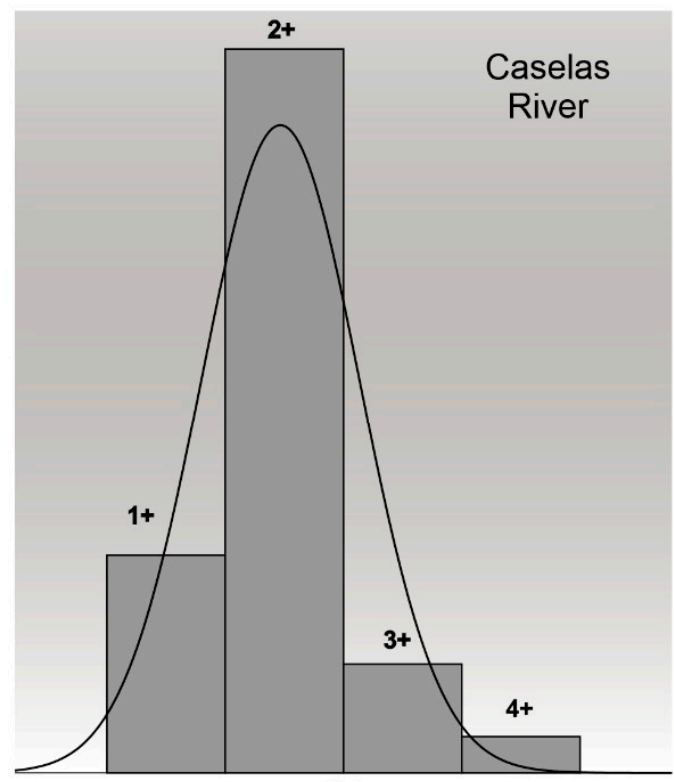

(b)

Figure 3. Frequency of age classes of G. lozanoi in the rivers (a) Pego and (b) Caselas. 


\subsection{Biomarkers: Glycogen, Lipids and Proteins}

The obtained values of glycogen $(\mathrm{mg} / \mathrm{g})$ in the specimens of the Pego River ranged between 0.03 and $0.17 \mathrm{mg} / \mathrm{g}$ and in the Caselas River between 0.05 and $0.17 \mathrm{mg} / \mathrm{g}$ (Tables S1 and S2). The statistical analysis did not show significant differences between the two populations (Table 5, Figure 4). The maximum lipid content (\%) of the individuals were $28.9 \%$ in the Pego River and 2.9\% in the Caselas River (Tables S1 and S2). The statistical analysis showed significant differences in the lipid content, being higher in the specimens from the Pego River (Table 5, Figure 4). The values of the protein content ranged between 28.88 and $75.82 \mathrm{mg} / \mathrm{g}$ in the Pego River and between 40.28 and $78.62 \mathrm{mg} / \mathrm{g}$ in the Caselas River. Significant differences were also found for this biomarker (Table 5, Figure 4).

Table 5. Average \pm standard error (range) of glycogen $(\mathrm{mg} / \mathrm{g})$, protein $(\mathrm{mg} / \mathrm{g})$ and lipids $(\%)$ concentration ( 60 specimens of G. lozanoi) of the two analyzed populations.

\begin{tabular}{lcccc}
\hline River & $\mathbf{N}$ & Glycogen $(\mathbf{m g} / \mathbf{g})$ & Lipids $(\%)$ & Proteins $(\mathbf{m g} / \mathbf{g})$ \\
\hline \multirow{2}{*}{ Pego } & \multirow{2}{*}{30} & $0.07 \pm 0.01$ & $5.4 \pm 1.1$ & $43.95 \pm 1.61$ \\
\multirow{2}{*}{ Caselas } & \multirow{2}{*}{30} & $0.080 \pm 0.17)$ & $(1.30-28.90)$ & $(28.88-75.82)$ \\
& & $(0.05-0.17)$ & $(1.10-2.90)$ & $58.92 \pm 1.92$ \\
& & & & \\
\hline
\end{tabular}

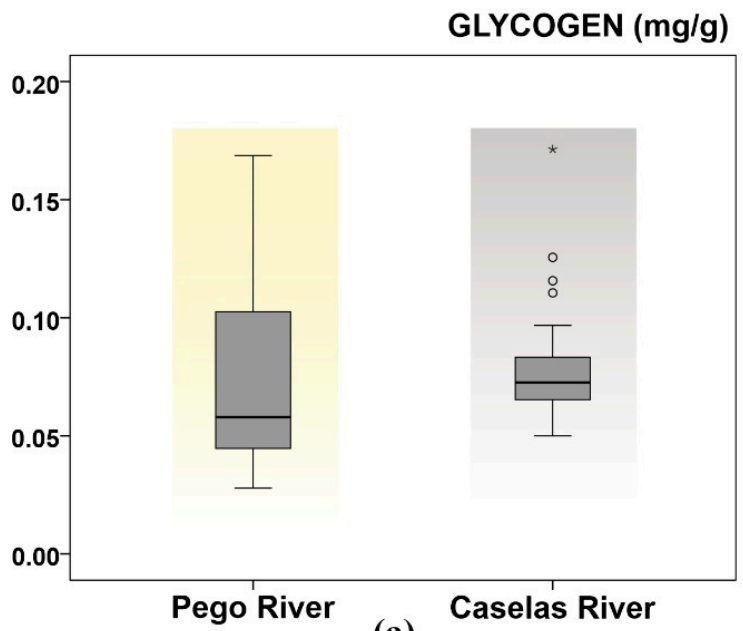

(a)

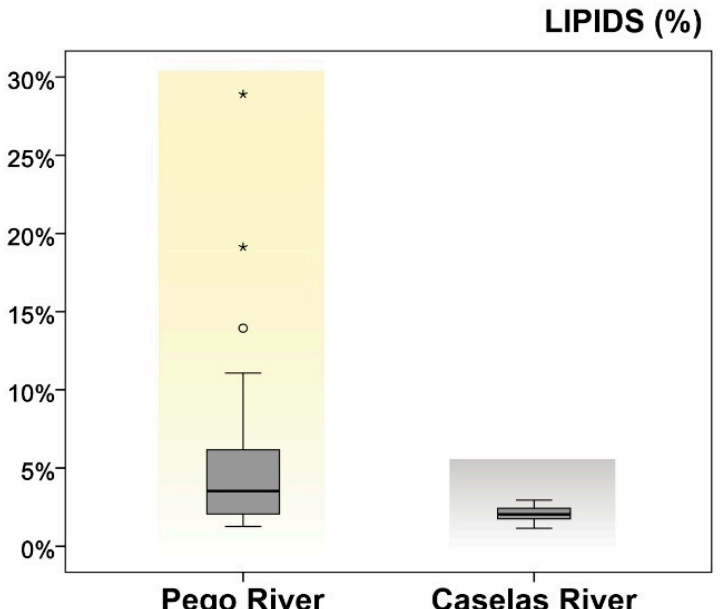

Pego River

(b)

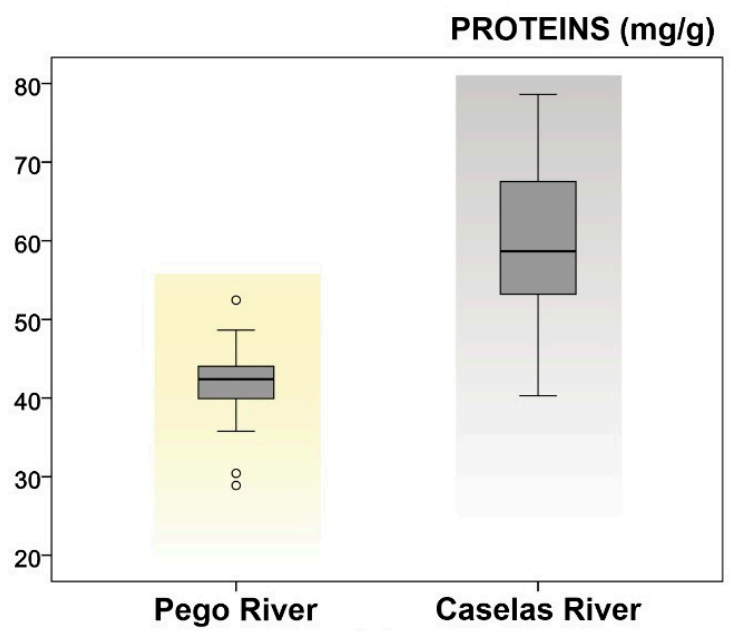

(c)

Figure 4. Box plot (median, quartiles, maximum and minimum) of the (a) glycogen, (b) lipids, and (c) proteins values of the individuals of the two studied populations of G. lozanoi. 


\section{Discussion}

Elton's classic work on the ecology of biological invasions [39] hypothesized that species-rich communities are more resistant to invasions than poorer ones. This raises the question of whether ecosystems, or more specifically biological communities, are saturated in relation to resource availability and use, which is directly related to the concept of "ecological niche". Hutchinson's concept [40] in contrast to Grinnell's idea of niche [41], addresses the notion that auto-ecological factors are not the only ones that determine the dimensions of the niche, but the role of the other species present in the community is decisive. As a consequence, it is possible to differentiate between the potential niche and the effective niche. The first includes the set of conditions in which a species can live and all the resources it can exploit, while the second refers to the conditions and resources in which a species can live in the presence of other species. In opposition, Hutchinson's paradox [42] and its resolution, that consider that ecosystems are rarely in equilibrium, eliminate the conceptual problem of competitive exclusion. This breaks the relationships of competition-exclusion $[43,44]$ and readjusts the relationships within communities and the dimensions of niches: there are no vacant niches, but there is the possibility of new species entering the community and readjusting the actual niches according to the availability of resources. Thus, communities are always more or less susceptible to invasion. However, resistance to invasion then increases with the number of species, as there is a more complete use of resources, so that a negative relationship can be expected between specific richness and invasibility [20].

The hydromorphological conditions of the two rivers considered here are similar [31]. However, both the state of oxidation of the nitrogenous compounds and the densities and dominances of the macroinvertebrate communities, and especially the values of the biotic index (with clear differences in the dominance of organisms resistant to organic pollution), indicate a state of nutrient enrichment in the Pego River. This, without generating significant oxygen deficits, increases primary and secondary production, allows a general increase in biomass and, consequently, a greater food supply and abundance of resources. In accordance with some authors [45-47] the discharge of organic matter, although slight, increases the amount of nutrients with the consequent enrichment of fish food, due to the increase of specific prey. Furthermore, studies under laboratory conditions showed that chronic exposure to moderately elevated non-ionized ammonium (the percentage is high in our case, considering the $\mathrm{pH}$ and temperature recorded) can lead to differences in growth and protein production in juvenile salmonids [48] and in the survival of eleutheroembryos. Additionally, while the number of fish species are similar, the relative proportions between native and exotic species are not, with a slightly greater proportion of the latter in the Pego River. This may reflect, as has been observed in other studies [49], a negative correlation between the abundance of native fish and that of non-native fish in ecosystems with a lower resistance to invasion. Consequently, the two rivers under consideration present similar ecological characteristics (hydromorphological conditions, riverbed banks, river-bank vegetation, etc.) but differ in their "ecological well-being".

The effect of potential predators on G. lozanoi and therefore on its invasiveness is also interesting. The density of potential predators in the Pego River is higher than that observed in the Caselas River (except for the eel, which is very similar) (Table 3). However, the density of G. lozanoi in the Pego River is almost double that found in the Caselas River (Table 3). A direct conclusion is that if the invasion capacity of G. lozanoi were really affected by the density of potential predators, the density of this species in the Pego River should be lower than in the Caselas River. The relationships and the effect of interspecific interactions is complex; therefore, further analysis would be needed to address this issue correctly.

Although the biometric parameters indicate a better general condition in the individuals of G. lozanoi of the Caselas River, the age class structure shows a higher mortality in the juvenile phases. This mortality may be related to more intense interspecific competition in a situation of greater resource scarcity, compared to the abundant production of the Pego River, as indicated by the macroinvertebrates data. 
In fish, carbohydrates are stored as glycogen in tissues and organs such as muscle and liver. Most of the ATP required for rough exercise (attacking prey, escaping from predators, and swimming against the current) is derived from the degradation of the glycogen stores in the target muscle and its consequent glycolysis [24]. Lipid storage and metabolism play a critical role in fish health as they determine energy use strategies, responses to environmental stress and reproductive success. Therefore, total lipids are a commonly used index in determining long-term growth and in measuring fish survival $[23,28]$. The amount of total protein provides a measure of long-term growth (weeks to months) and is generally higher under stable conditions and under environmental stress. The obtained energy reserve levels are significantly different between the two considered populations of G. lozanoi. Individuals from the Pego River have higher lipid values than those from the Caselas River, which in turn shows a greater proteins level.

The differences in the energy reserve levels can be related with the trophic base availability. In the Pego River the dominant groups of the macrobenthos are represented by lipid-rich taxa $[50,51]$. Under this condition it is frequent to observe changes in the general behavior of fish [52-54] and in their feeding strategy, arousing behaviors such as hyperphagia [27]. In addition, for G. lozanoi it was observed that when individuals gain size, the diet differs, and predation on protein-rich groups, such as caddisflies (Trichoptera) or crustaceans, increases. Therefore, the available preys and the excess of lipid-rich taxa can reshape the trophic niche of the entire community through readjustment of fish feeding strategies [46], thus decreasing resistance to invasion, or at least favoring the ecological fitness of non-native species, which facilitates their invasiveness.

\section{Conclusions}

The complexity of the relationship between environmental factors, interspecific competition, and intrinsic traits of the species are important to explain the invasive success of Gobio lozanoi. For the first time, the invasiveness of this species is analyzed in the Pego and Caselas rivers. In addition, biomarkers are proposed as a useful tool to determinate the potential success of non-native species.

The habitat quality, competing species, and food supply determinate a difference in the invasibility between the two studied rivers, with a better ecological status, and therefore a higher resistance to invasion in the Caselas River.

In general, it is accepted that a previously disturbed ecosystem has less "biotic resistance" to new disruptions. In this study the Pego River presents an organic enrichment with a notable increase in secondary production that is reflected in the G. lozanoi population, well-structured and with individuals with higher lipid values. Conversely, individuals of the Caselas River, that has a better ecological status, show higher protein values and low survival rate of juveniles.

Lipid level is shown here as a good indicator of invasiveness. This is an example of an increase in the invasibility of an ecosystem through an increase in resource availability. Under a moderate organic enrichment, production and food availability for the entire fish community are increased, while habitability conditions are maintained. This allows a breakdown of competition between native and non-native species and the establishment of new interactions and ecological niche dimensions.

Supplementary Materials: The following are available online at https:/ / www.mdpi.com/article/ $10.3390 /$ w13213043/s1, Table S1. Furcal length (cm), weight $(\mathrm{g})$, condition factor $(\mathrm{k})$ and glycogen $(\mathrm{mg} / \mathrm{g})$, protein $(\mathrm{mg} / \mathrm{g})$ and lipids (\%) concentration of the of the individuals of G. lozanoi in Pego River. Table S2. Furcal length (cm), weight $(\mathrm{g})$, condition factor $(\mathrm{k})$ and glycogen $(\mathrm{mg} / \mathrm{g})$, protein $(\mathrm{mg} / \mathrm{g})$ and lipids (\%) concentration of the of the individuals of G. lozanoi in Caselas River.

Author Contributions: Conceptualization, F.C.; methodology, F.C., R.V.-L., S.B., M.d.C.C., D.J.N. and J.S.-H.; software, M.d.C.C. and S.B.; validation, F.C., R.V.-L. and D.J.N.; formal analysis, S.B.; investigation, F.C., R.V.-L., S.B., M.d.C.C., D.J.N. and J.S.-H.; resources, F.C., R.V.-L., S.B., M.d.C.C., D.J.N. and J.S.-H.; data curation, R.V.-L.; writing-original draft preparation, M.d.C.C. and S.B.; writing-review and editing, M.d.C.C., R.V.-L. and J.S.-H.; visualization, R.V.-L.; supervision, F.C.; 
project administration, F.C.; funding acquisition, F.C. All authors have read and agreed to the published version of the manuscript.

Funding: This work is part and was funded by the project "Protection and conservation of migratory fish in the International Section of the Miño River and its tributaries" (0016_MIGRA_MINO_MINHO_1_E)".

Institutional Review Board Statement: Protocols used in this study conform to the ethical laws of the country and have been reviewed by the ethics committee of the University of Santiago de Compostela and the regional government (Xunta de Galicia).

Informed Consent Statement: Not applicable.

Data Availability Statement: Data from this research are available from the corresponding authors upon reasonable request.

Acknowledgments: Sampling was carried out by the team of the Laboratory of Hydrobiology of the University of Santiago de Compostela. We would like to thank all those who participated in the sampling activities. The authors are especially grateful to Felipe Arnoso Martínez for his participation in some of the laboratory analysis.

Conflicts of Interest: The authors declare no conflict of interest.

\section{References}

1. Mack, R.N.; Simberloff, D.; Mark Lonsdale, W.; Evans, H.; Clout, M.; Bazzaz, F.A. Biotic invasions: Causes, epidemiology, global consequences, and control. Ecol. Appl. 2000, 10, 689-710. [CrossRef]

2. Sala, O.E.; Chapin, F.S.; Armesto, J.J.; Berlow, E.; Bloomfield, J.; Dirzo, R.; Leemans, R. Global biodiversity scenarios for the year 2100. Science 2000, 287, 1770-1774. [CrossRef]

3. Meyerson, L.A.; Mooney, H.A. Invasive Alien Species in an Era of Globalization. Front. Ecol. Environ. 2007, 5, 199-208. [CrossRef]

4. Simberloff, D. Biological invasions: What's worth fighting and what can be won? Ecol. Eng. 2014, 65, 112-121. [CrossRef]

5. Ricciardi, A.; Cohen, J. The invasiveness of an introduced species does not predict its impact. Biol. Invasions 2007, 9, 309-315. [CrossRef]

6. Hui, C.; Richardson, D.M.; Landi, P.; Minoarivelo, H.O.; Garnas, J.; Roy, H.E. Defining invasiveness and invasibility in ecological networks. Biol. Invasions 2016, 18, 971-983. [CrossRef]

7. Smith, P.R.; Davey, S. Evidence for the competitive exclusion of Aeromonas salmonicida from fish with stress-inducible furunculosis by a fluorescent pseudomonad. J. Fish Dis. 1993, 16, 521-524. [CrossRef]

8. Simon, K.S.; Townsend, C.R. Impacts of freshwater invaders at different levels of ecological organisation, with emphasis on salmonids and ecosystem consequences. Fresh. Biol. 2003, 48, 982-994. [CrossRef]

9. Matsuzaki, S.I.S.; Sasaki, T.; Akasaka, M. Consequences of the introduction of exotic and translocated species and future extirpations on the functional diversity of freshwater fish assemblages. Glob. Ecol. Biogeogr. 2013, 22, 1071-1082. [CrossRef]

10. Dorenbosch, M.; Bakker, E.S. Effects of contrasting omnivorous fish on submerged macrophyte biomass in temperate lakes: A mesocosm experiment. Fresh. Biol. 2012, 57, 1360-1372. [CrossRef]

11. Hobbs, R.J. Invasive Species in a Changing World; Mooney, H.A., Hobbs, R.J., Eds.; Island Press: Washington, DC, USA, $2000 ;$ p. 457.

12. McNeely, J. Invasive Species: A Costly Catastrophe for Native Biodiversity. Land Use Water Resour. Res. 2001, 2, 1-10.

13. Andersen, M.C.; Adams, H.; Hope, B.; Powell, M. Risk assessment for invasive species. Risk Anal. Int. J. 2004, $24,787-793$. [CrossRef] [PubMed]

14. Gurevitch, J.; Padilla, D.K. Are invasive species a major cause of extinctions? Trends. Ecol. Evol. 2004, 19, 470-474. [CrossRef] [PubMed]

15. EEA (European Environment Agency). Halting the Loss of Biodiversity by 2010: Proposal for a First Set of Indicators to Monitor Progress in Europe; EEA Technical Report No. 11/2007; European Environment Agency: Copenhagen, Denmark, 2007 ; p. 186.

16. Cobo, F.; Vieira-Lanero, R.; Rego, E.; Servia, M.J. Temporal trends in non-indigenous freshwater species records during the 20th century: A case study in the Iberian Peninsula. Biodivers. Conserv. 2010, 19, 3471-3487. [CrossRef]

17. Doadrio, I.; Madeira, M.J. A new species of the genus Gobio Cuvier, 1816 (Actinopterygii, Cyprinidae) from the Iberian Peninsula and southwestern France. Graellsia 2004, 6, 107-116. [CrossRef]

18. Alpert, P.; Bone, E.; Holzapfel, C. Invasiveness, invasibility and the role of environmental stress in the spread of non-native plants. PPEES 2000, 3, 52-66. [CrossRef]

19. Byers, J.E.; Noonburg, E.G. Scale dependent effects of biotic resistance to biological invasion. Ecology 2003, 84, 1428-1433. [CrossRef]

20. Brown, J.H.; Lomolino, M.V. Biogeography; Sinauer: Sunderland, MA, USA, 1998; p. 691.

21. Ríos, H.F.; Vargas, O. Ecología de las especies invasoras. Pérez-Arbelaezia 2003, 14, 119-148.

22. Lonsdale, W.M. Global patterns of plant invasions and the concept of invasibility. Ecology 1999, 80, 1522-1536. [CrossRef] 
23. Beckman, B.; Larsen, D.; Sharpe, C.; Lee-Pawlak, B.; Schreck, C.; Dickhoff, W. Physiological status of naturally reared juvenile spring Chinook salmon in the Yakima river: Seasonal dynamics and changes associated with smolting. Trans. Am. Fish. Soc. 2000, 129, 727-753. [CrossRef]

24. Smutná, M.; Vorlová, L.; Svobodová, Z. Pathobiochemestry of ammoniain the internal environment of fish. Acta Vet. Brno 2002, 71,169-181. [CrossRef]

25. Quintana, C.F. Respuestas neuroendocrinas al estrés en peces teleósteos. Rev. Ictiol. 2002, 10, 57-78.

26. Sánchez, J.; Barca, S.; Vieira-Lanero, R.; Servia, M.J.; Cobo, F. Cambios en la alimentación y en los niveles de glucógeno de la trucha común (Salmo trutta Linné, 1758) por efecto de la contaminación orgánica. AEMS-Ríos Con Vida 2008, 82, 14-16.

27. Cobo, F.; Sánchez, J.; Vieira, R.; Servia, M. Organic pollution induces domestication like characteristics in feral populations of brown trout (Salmo trutta). Hydrobiologia 2013, 705, 119-134. [CrossRef]

28. Post, J.; Parkinson, E. Energy allocation strategy in age-0 fish: Allometry and survival. Ecology 2001, 82, 1040-1051. [CrossRef]

29. Barca, S. Biomarcadores Metabólicos y de Reserva Energética en Lamprea Marina (Petromyzon marinus Linnaeus, 1758). Ph.D. Thesis, Universidade de Santiago de Compostela, A Coruña, Spain, 2016.

30. Villarroel, M.J.; Sancho, E.; Andreu-Moliner, E.; Ferrando, M.D. Biochemical stress response in tetradifon exposed Daphnia magna and its relationship to individual growth and reproduction. Sci. Total Environ. 2009, 407, 5537-5542. [CrossRef]

31. Vieira-Lanero, R.; Servia, M.J.; Barca, S.; Couto, M.T.; Rivas, S.; Sánchez, J.; Nachón, D.; Silva, S.; Gómez-Sande, P.; Morquecho, C.; et al. Índices de Calidad de la Vegetación de Ribera y del Hábitat Fluvial en Los Afluentes de la Margen Española del Baixo Miño. In V Simposio Ibérico Sobre a Bacia Hidrográfica do Rio Minho; Câmara Municipal de Vila Nova de Cerveira: Vila Nova de Cerveira, Portugal, 2010; pp. 79-88.

32. Barca, S.; Vieira-Lanero, R.; Servia, M.J.; Couto, M.T.; Rivas, S.; Sánchez, J.; Nachón, D.; Silva, S.; Gómez-Sande, P.; Morquecho, C.; et al. Nuevos datos sobre las características fisicoquímicas del río Miño y sus afluentes de la margen española. In $V$ Simposio Ibérico Sobre a Bacia Hidrográfica do Rio Minho; Câmara Municipal de Vila Nova de Cerveira: Vila Nova de Cerveira, Portugal, 2010; pp. 131-137.

33. Alba-Tercedor, J.; Sánchez-Ortega, A. Un método rápido y simple para evaluar la calidad biológica de las aguas corrientes basado en el de Hellawell (1978). Limnetica 1988, 4, 51-56.

34. González, M.; Cobo, F. Macroinvertebrados de las Aguas Dulces de Galicia; Hércules, Ed.; Hércules Ediciones: A Coruña, Spain, 2006; 175p.

35. Amat-Trigo, F.; Oliva-Paterna, F.J.; Verdiell-Cubedo, D.; Ruiz-Navarro, A.; Torralva, M. Edad y crecimiento de Gobio lozanoi Doadrio y Madeira, 2004 (Cypriniformes: Cyprinidae) en gradientes longitudinales de la cuenca del río Segura (SE Península Ibérica). An. Biol. 2013, 35, 109-121.

36. Van Handel, E. Estimation of glycogen in small amounts of tissue. Anal. Biochem. 1965, 11, 256-265. [CrossRef]

37. Folch, J.; Lees, M.; Stanley, G.H. Simple method for the isolation and purification of total lipids from animal tissues. J. Biol. Chem. 1957, 226, 497-509. [CrossRef]

38. Bligh, E.G.; Dyer, W.J. A rapid method of total lipid extraction and purification. Can. J. Biochem. Physiol. 1959, 37, 911-917. [CrossRef] [PubMed]

39. Elton, C. The Ecology of Invasions by Animals and Plants; Methuen Publisher Ltd.: London, UK, 1958; p. 196.

40. Hutchinson, G. Concluding remarks. Cold Spring Harb. Symp. Quant. Biol. 1957, 22, 415-427. [CrossRef]

41. Grinnell, J. Presence and absence of animals. Chron. Univ. Calif. 1928, 30, 429-450.

42. Hutchinson, G. The paradox of the plankton. Am. Nat. 1961, 95, 137-145. [CrossRef]

43. Connell, J. Diversity in tropical rain forests and coral reefs. Science 1978, 199, 1302-1310. [CrossRef] [PubMed]

44. Townsend, C.; Scarsbrook, M.; Dolédec, S. The Intermediate Disturbance Hypothesis, Refugia, and Biodiversity in Streams. Limnol. Oceanogr. 1997, 42, 938-949. [CrossRef]

45. Adams, S.M.; Ham, K.D.; Greeley, M.S.; LeHew, D.E.; Hinton, R.F.; Saylor, C.F. Downstream gradients in bioindicator responses: Point source contaminant effects on fish health. Can. J. Fish. Aquat. Sci. 1996, 53, 2177-2187. [CrossRef]

46. Porter, C.; Janz, D.M. Treated municipal sewage discharge affects multiple levels of biological organization in fish. Ecotoxicol. Environ. Saf. 2003, 54, 199-206. [CrossRef]

47. Speranza, E.D.; Colombo, J.C. Biochemical composition of a dominant detritivorous fish Prochilodus lineatus along pollution gradients in the Paraná-Río de la Plata Basin. J. Fish Biol. 2009, 74, 1226-1244. [CrossRef]

48. Wood, C.M. Dogmas and controversies in the handling of nitrogenous wastes: Is exogenous ammonia a growth stimulant in fish? J. Exp. Biol. 2004, 207, 2043-2054. [CrossRef]

49. Kühn, I.; Klotz, S. Urbanization and homogenization-Comparing the floras of urban and rural areas in Germany. Biol. Conserv. 2006, 127, 292-300. [CrossRef]

50. Cobo, F.; Mera, A.; González, M.A. Análisis químico y valor energético de algunas familias de insectos heterometábolos dulceacuícolas. Boletín AeE 1999, 23, 213-221.

51. Cobo, F.; Mera, A.; González, M.A. Análisis químico y contenido energético de algunas familias de insectos holometábolos dulceacuícolas. NACC 2000, 10, 1-12.

52. Shingles, A.; McKenzie, D.J.; Taylor, E.W.; Moretti, A.; Butler, P.J.; Ceradini, S. Effects of sublethal ammonia exposure on swimming performance in rainbow trout (Oncorhynchus mykiss). J. Exp. Biol. 2001, 204, 2691-2698. [CrossRef] [PubMed] 
53. Tudorache, C.; Blust, R.; De Boeck, G. Social interactions, predation behaviour and fast start performance are affected by ammonia exposure in brown trout (Salmo trutta L.). Aquat. Toxicol. 2008, 90, 145-153. [CrossRef] [PubMed]

54. McKenzie, D.J.; Shingles, A.; Claireaux, G.; Domenici, P. Sublethal concentrations of ammonia impair performance of the teleost fast-start escape response. Physiol. Biochem. Zool. 2009, 82, 353-362. [CrossRef] [PubMed] 